\title{
Development of small medium enterprises of maize processed food products as a locomotive of Gorontalo District's economy
}

\author{
Amir Halid \\ Agribusiness Department, Faculty of Agriculture, Universitas Negeri Gorontalo, \\ Indonesia
}

Correspondence author email: amirhalid_ung@yahoo.com

\begin{abstract}
This study aims to analyze the development of small medium enterprises (SMEs) of maize processed product as a locomotive of Gorontalo District's economy. Primary and secondary data were used for this study. Data were analyzed descriptively and regression analysis was conducted to analyze the effect of the components of production costs on the selling prices of maize processed food products and the effect of selling prices on SMEs revenues. The results of the study found that the potential for development of SMEs of maize processed food products in Gorontalo District is quite prospective because human resources and raw materials were still cheap and easily obtained. On the demand side, maize processed products are also relatively high on demand. Maize processed product has been an alternative substitute for pastries which are always served by Muslims on religious observances. In increasing the competitiveness of maize processed products, it is necessary to pay attention and make raw material costs and labor costs efficient. Those two cost components have a significant effect on the selling prices of maize processed food products.
\end{abstract}

Keywords: Maized, Food products, Economy, SMEs

JEL classification: L25, M21, Q12

\section{INTRODUCTION}

There are many secondary product and by other product is produced by small medium enterprise and manufacture and also marketed in the world such as in United Stated of American is highest level produced and consumed, followed by Asian Countries like China People of Republic and also African and Latin American, (Mejia, 2003).

The maize commodity is planted by farmers in high land of Mexico, Peru, Ecuador and Also Bolivia since 5000 ago. This commodity is developed and brought by occupation country lake Portugal, Spain, and Holland into reviews their occupation countries including Indonesia so, that is the way also this commodity and become has developed one of the resource of food (IITA, 1982)

Maize is resource based food in population of the world, many people like in Africa's food made from maize and also some countries in Asia like China, India, Indonesia maize become one the special food. In the other hand maize not only resource of food for human kind but also it's the resource of food for animals, (Gwirtz, \& Garcia-Casal, 2014). 
Since the formation of Gorontalo Province, on 12 February 2000, the question that always arises in the minds of the community is how far the impact of the corn agropolitan program can improve the welfare of farmers in particular and the people of Gorontalo in general. The answer is very dependent on the multiply effect of the maized agropolitan program itself (Muhammad, 2008).

The agricultural sector basically has a varied land area in the size of the soil texture, because it is affected by the rainy climate is not too good compared to other regions in Indonesia. The logical consequences of this indicator more professional provide motivation for related agencies to manage maize farming; this has become part of the obstacles encountered today, why, because Gorontalo is tin the fifth position of poor province in Indonesia, also is in the eight position of Gross Regional Domestic Product in national level (BPS, 2018).

The competitiveness of maize products currently lies in its downstream industry, no longer in primary products, where domestic added value that can be created in downstream products can double than the primary product. Maize is a second carbohydrate source commodity after rice, which is very important for food security. Also maize plays an important role in the husbandry of feed industry and the food industry.

Besides being able to fulfil the daily needs the people of Gorontalo, maized can also be processed for various products such as maize sticks, maize oil, maize flour the which is known as maize starch, poultry feed, fish feed, and many more. Maize waste can also be empowered into various products such as maize waste into ruminants feed, maize waste into organic fertilizer, maize cobs into charcoal briquettes, and maize husk can be processed to be used as flowers, dodol pads, basic material for clothes, table mats and many other unique products.

Based on the survey results that maize seeds (yield) in Gorontalo beside food for daily use, they are also sold to other places to neighbour countries or neighbour provinces. Maize seeds (yield) are generally not processed into other processed products that can increase of the economic value of the product. As an illustration, the price ratio of $1 \mathrm{~kg}$ of maize worth Rp. 3,200 if it has been processed into animal feed price reaches 5 times the original price when not processed. By processing maize kernels into basic ingredients, animal feed will increase of the economic value of the product.

Based on the explanation above, this study aims to analyze the development of SMEs of maize processed products as a locomotive of Gorontalo District's economy.

\section{RESEARCH METHOD}

The data used consists of secondary data and primary data. Secondary daya includes data on the number of SME units, labors, investment value, production costs, and production value, both in SMEs of maize and non-maize processed products. Data were obtained from Cooperative, Industry, and Trade Office of Gorontalo District. Primary data were obtained from surveys on SMEs of maize processed products in Toidito village, Pulubala sub-district, Gorontalo District. The village is the center for the development of SMEs of maize processed products.

Primary data collection of SMEs of maize processed products in Toidito village was conducted by observation, independent surveys, structured questionnaire interviews, and focus group discussion. Data were analyzed descriptively and regression analysis was conducted to analyze the effect of the components of production costs on the selling prices of maize processed food products and the effect of selling prices on the revenue of SMEs. 


\section{RESULTS AND DISCUSSION}

\section{Maize processed products as an economy locomotive of Gorontalo District}

The development of SMEs of maize processed products in Gorontalo District has good prospects. SMEs of maize processed products are able to produce 480.68 percent of the total investment. Otherwise, SMEs of processed non-maize products are only able to produce a production value of 82.82 percent of the total investment. These figures can be seen in Table 1.

Table 1. Number of units, labor, investment and production of SMEs in processed food with maize and non-maize-based, Gorontalo District, 2016

\begin{tabular}{lcccccc}
\hline \multicolumn{1}{c}{ SMEs type } & Unit & Labor & $\begin{array}{c}\text { Labor } \\
\text { per unit }\end{array}$ & $\begin{array}{c}\text { Investment } \\
\text { per unit } \\
\text { (Rp. 000) }\end{array}$ & $\begin{array}{c}\text { Production } \\
\text { per unit } \\
\text { (Rp. 000) }\end{array}$ & $\begin{array}{c}\text { Production/ } \\
\text { Investment } \\
(\%)\end{array}$ \\
\hline maize based & 24 & 71 & 2.96 & 18,056 & 86,792 & 480.68 \\
non maize based & 224 & 984 & 4.39 & 96,402 & 79,840 & 82.82 \\
\hline
\end{tabular}

Source: Department of Industry and Commerce Gorontalo District

However, Table 1 also shows that the number of SME units of maize processed food product was still relatively small. There were only 24 units of SME of maize processed food product. On the other hand, there were 224 units of SME of non-maize processed food product. In addition, in terms of labor absorption, it was also relatively low. The average number of labors in SME of maize processed food product was only 2.96 per business unit, whereas for SME of non-maize processed food product, it reached 4.39 per business unit.

There are various types of maize processed products, namely sticks, dodol, pie, maize milled, flour and maize rice. Of these types, SME that produce maize milled was the largest in number, as many as 10 units or 41.67 percent of the total SMEs of maize processed food products (Table 2). Furthermore, in terms of labor absorption, SMEs that produce stick and dodol had the highest labor absorption of 7 workers per business unit.

Table 2. Number of units, labor, investment and production of SMEs of maize processed products, Gorontalo District, 2016

\begin{tabular}{lcrcrrr}
\hline $\begin{array}{l}\text { Processed } \\
\text { product }\end{array}$ & $\begin{array}{c}\text { Number } \\
\text { units of } \\
\text { SMEs }\end{array}$ & Labor & $\begin{array}{c}\text { Labor } \\
\text { per unit }\end{array}$ & $\begin{array}{c}\text { Investment } \\
\text { per unit } \\
\text { Rp. 000) }\end{array}$ & $\begin{array}{c}\text { Production } \\
\text { per unit } \\
\text { (Rp. 000) }\end{array}$ & $\begin{array}{c}\text { Production/ } \\
\text { Investment } \\
(\%)\end{array}$ \\
\hline Stick & 2 & 14 & 7 & 32,533 & 195,000 & 599.39 \\
Dodol & 2 & 14 & 7 & 41,217 & 197,000 & 477.96 \\
Pie & 1 & 6 & 6 & 15,000 & 43,200 & 288.00 \\
Maize milled & 10 & 20 & 3 & 4,500 & 56,000 & 1244.44 \\
Flour & 3 & 6 & 2 & 5,000 & 7,200 & 144.00 \\
Maize rice & 6 & 11 & 1.8 & 10,083 & 22,350 & 221.66 \\
\hline
\end{tabular}

Source: Department of Industry and Commerce Gorontalo District

In terms of the ratio of production-investment value, the type of corn processed products has the best prospects among various types of processed corn products in Gorontalo Regency. The production-investment value ratio for this type of product is $1,244.44$ percent. On the contrary the lowest ratio is for SMEs that produce flour.

The development of SMEs of maize processed products in Gorontalo District has good prospects because of the enormous support of human resources, especially among women as laborers in SMEs. It is also supported by the availability of raw material sources which are still cheap and easily obtained. 
On the demand side, maize processed products are also relatively high on demand. Maize processed product has been an alternative substitute for pastries which are always served by Muslims on religious observances. Another thing that needs to be considered is the demand from outside Gorontalo continues to increase. However, the fulfillment of request from outside Gorontalo is still constrained by the pricey transportation costs of products.

\section{Toidito Village: development center of small and medium industries of corn}

Toidito Village as a center for the development of small-scale industries based on maize processing. The potential of the area in this village is dominated by dry land farming systems that are dominated by plains that are used by the community by cultivating various agricultural, including maize, peanuts, cayenne pepper, banana, vegetables and annual crops, namely coconut

There are a number of leading agricultural commodities in the region but have not yet entered the downstream phase so that the economic added value of this commodity is still small. There is one commodity that has been included in the downstream phase items, namely the coconut commodity the which has been developed with various derivative products including nata de coco, coconut cake, packaged coconut water but begins to experience a decline in production due to the decreasing coconut supply of raw materials from cassava farmers as well as the which has been processed into maize starch. Maize commodities have not experienced downstream progress. Until now has only been developed into a shell maize with a drying system using technology

Based on the result of the survey, basically there is potential for developing SMEs in Toidito Village in the future. It can be seen from the high motivation of the SMEs' actors to continue their business and the willingness to gradually improve various aspects of the business. SMEs' actors also have high curiosity and are willing to open up to receive new information and ideas.

Coaching conducted by researchers in the last three years $(2016-2018)$ have proven to be able to increase the quantity and quality of maize processed production such as Limboto lake shrimp flavored sticks, banana root sticks (stik akar pisang), and sweet corn dodol (dodol jagung manis). These products have also been able to penetrate the markets outside Gorontalo District, including markets in the South Bolaang Mongondow District and North Bolaang Mongondow which are the regions of North Sulawesi Province.

\section{Effect of components of production costs on selling prices and its impact on the revenues of SMEs of maize processed products}

The model estimation of the effect of production costs' components on selling prices of maize processed products is given in Table 3. Simultaneously, all cost components have a significant effect on the selling prices of maize processed products. It can be seen from the $\mathrm{F}$ probability value $<0.01$. Furthermore, the model has an Rsquare value of 0.923 which indicates that 92.3 percent of the selling prices is determined by the component of production costs. The amount of the contribution of the cost component to the selling prices is in line with Sunarto (2004) who argued that the factor with a high certainty to determine the selling prices is the production costs. Research by Slamet and Sumarli (2002) on small industry of pressed tile in Magelang District found that production costs contributed to the selling prices of 21 percent.

Partially, of the four cost components, only two of them have a significant effect, namely raw material costs and labor costs. The other two components, namely transport costs and rental costs, have no significant effect on selling prices. 
Table 3. The model estimation of the effect of production costs' components on selling prices of maize processed products

\begin{tabular}{lccc}
\hline Variable & Coefficient $(\beta)$ & t-stat & Sig. (P-value) \\
\hline Raw Materials & 0.721 & 5.883 & 0.000 \\
Labor Wage & 1.059 & 3.390 & 0.003 \\
Transport Charges & -0.269 & -0.274 & 0.787 \\
Tool Rent & -1.203 & -1.093 & 0.286 \\
\hline F-statistic $=65.621$ & $\mathrm{R}^{2}=.923$ & & \\
\hline
\end{tabular}

There is a positive and significant influence of raw material costs on the selling prices of maize processed products. This finding is in accordance with the findings of several MSME researchers. Study by Sayyida (2014) showed one of the production variables, direct labor cost, affected the selling prices of the product, but the effect was relatively low. Aprilla's research on the bread industry in Padang City found that a 3.11 percent increase in raw material costs caused an increase in production costs.

Labor costs have a positive and significant effect on the selling prices of maize processed products. This is in line with the research by Sayyida (2014) which showed one of the production variables, direct labor cost, affected the selling prices of coconut aminos in Sumenep, but the effect was relatively low. This research also supports the results of Ndenge's research (2015) on SMEs in Ganteng Province, South Africa. Transport cost has no significant effect on the selling prices of maize processed products. The same thing is also applied to the rent cost of equipment. It is due to the small composition of transport costs and rent cost of equipment from the total costs of production as a whole in producing maize processed food products. This fact contradicts the results of Kinyua's research (2014) on SMEs in Nakuru Tawon, Kenya that found a significant effect of transport costs on the selling prices of MSME products. Likewise, it also contradicts the findings of Moorthy, Tan, Choo, Wei, Ping \& Leong's research (2012) on SMEs in Malaysia..

Furthermore, model estimation of the effect of selling prices on revenues is given in Table 7. Based on Table 7, it can be seen that the selling prices has a significant effect on revenues of SMEs of maize processed products. Referring to the coefficient value, it indicates that an increase in the selling prices of Rp. 1 will be able to increase revenue by Rp.0.636.

Table 4. The model estimation of the effect of selling prices on revenues

\begin{tabular}{lccc}
\hline Variable & Regression coefficient $(\beta)$ & t-stat & Sig. (P-value) \\
\hline Selling prices & .636 & 9.631 & 0,000 \\
\hline $\mathrm{R}^{2}=.788$ & & & \\
\hline
\end{tabular}

The significant effect of selling prices on revenues of SMEs of maize processed products supports several related studies such as a research by Jonga, et al. (2018) on SMEs in Kenya, and a research by Malik, Antara, and Sulaeman (2017) on SMEs in Palu City.

\section{CONCLUSION AND RECOMMENDATION}

\section{Conclusion}

The development of SMEs of maize processed products in Gorontalo District has good prospects because of the support of human resources, especially the workforce of housewives and raw material sources that are still cheap and easily obtained. On the demand side, maize processed products are also relatively high on demand. Maize 
processed product has been an alternative substitute for pastries which are always served by Muslims on religious observances.

Two cost components, namely raw material costs and labor costs, have a significant effect on the selling prices of maize processed food products. Based on the finding, it can be concluded that the competitiveness of maize processed products is determined by the efforts of SMEs to make both costs efficient.

\section{Recommendation}

To maintain and to improve the capacity of SME at process of maize productions should have permanent legal cooperation between government, businessman, nongovernment organization and university research institution.

Furthermore, in order to improve the competitiveness of maize processed products, the government needs to formulate policies to strengthen internal markets such as by increasing demand for maize processed products in government events.

\section{REFERENCES}

Aprilla, S.W. (2009). Pengaruh Kenaikan Harga Bahan Baku terhadap Biaya Produksi dan Keuntungan Industri Roti Pryangan Bakery di Kota Padang. Thesis. Universitas Andalas

BPS. (2018). Produk Domestik Regional Bruto. Jakarta: BPS

Gwirtz, J.A., \& Garcia-Casal, M.A. (2014) Processing Maize Flour And Corn Meal Food Products, Annal of the New York Academy of Sciences, 1312(1), 66 - 75

IITA. (1982). Maize Product Manual. Ibadan Nigeria: International Institute of Tropical Agriculture (IITA).

Jonga, M., Waiganjo, E., \& Njeru, A. (2018). Influence of Product Quality on Organizational Performance of Seed Maize Companies in Kenya. Journal of Agricultural Science, 10(5), 109 - 116

Kinyua, A.N. (2014). Factors Affecting The Performamce of Small and Medium Enterprise in the Jua Kali Sector in Nakuru Tawon, Kenya. Journal of Business and Management, 16 (1), 80-93

Malik, SR., Antara, M. \& Sulaeman. (2017). Faktor- Faktor yang Mempengaruhi Pendapatan Industri Bawang Goreng di Kota Palu. Agroland, 24(1), 36 - 48

Mejia, D. (2003). Maize: Post Harvet Operation. Rome: Food and Agriculture Organization of The United Nations (FAO), AGST

Moorthy, M.K., Tan, A., Choo, C., Wei, C.S., Ping, J.T.Y.P., \& Leong, T.K (2012). A Study of Factors Affecting the Performance of SMEs in Malaysia. International Journals of Academic Research in Business and Social Science. 12(4), $224-239$

Muhammad, F. (2008). Reinventing Local Government, Pengalaman dari Daerah. Jakarta: PT Elex Media Computindo - Kompas Gramedia.

Ndege, M. (2015). Factors That Affect the Growth and Development of Small, Micro and Medium-Sized Business Enterprise in the Vaal triengle Region of Ganteng Province in South Africa. European Journal of Business, Economics and Accounting, 3(3), 73 - 100

Sayyida (2014). Pengaruh Biaya Produksi terhadap Laba Perusahaan. Jurnal Performance Bisnis dan Akuntansi. 4(1), 1 - 13

Slamet, A dan Sumarli (2002) Pengaruh Perkiraan Biaya Produksi dan Laba yang Diinginkan terhadap Harga Jual pada Industri Kecil Genteng Pres. Jurnal Ekonomi dan Manajemen Dinamika. 11(2), 45 - 56

Sunarto. (2004). Akuntansi Biaya. Yogyakarta: AMUS Yogyakarta. 